Huzaifa Katarudin, Nora Eka Putril Pengaruh Literasi Politik terhadap Partisipasi Politik Pemilih Pemula pada Pemilukada Kota Pariaman Tahun 2018

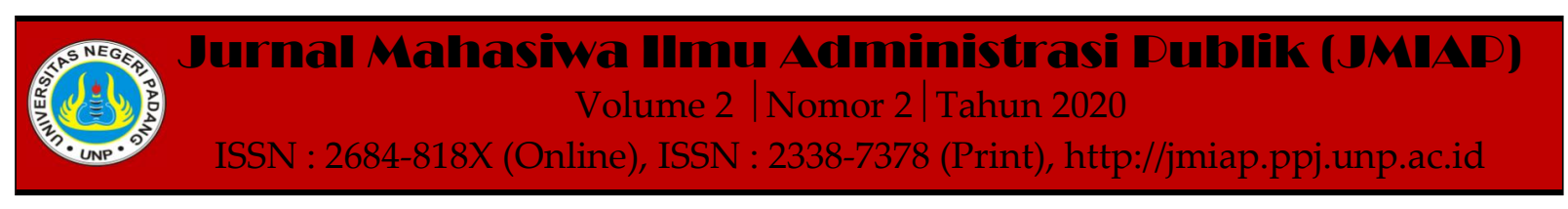

\title{
PENGARUH LITERASI POLITIK TERHADAP PARTISIPASI POLITIK PEMILIH PEMULA PADA PEMILUKADA KOTA PARIAMAN TAHUN 2018
}

\author{
Huzaifa Katarudin ${ }^{1(a)}$, Nora Eka Putri ${ }^{2(b)}$ \\ ${ }^{1}$ Jurusan Ilmu Administrasi Negara, Universitas Negeri Padang \\ ${ }^{2}$ Jurusan Ilmu Administrasi Negara, Universitas Negeri Padang \\ a)huzaifakatarudinumar@gmail.com, ${ }^{b)}$ noraekaputri@fis.unp.ac.id
}

\begin{abstract}
The aim of this study is to analyze the effect of political literacy on political participation of Novice voters in the 2018 regional elections for Pariaman city. The not optimal participation of Novice voters in regional elections and the relatively high level of apathy for first-time voters and minimal knowledge of politics makes first-time voters vulnerable to mobilization, this is a reason for researchers to make novice voters the object of research. The method used in this research uses a quantitative approach with a survey method. The population in this study were adolescents or people aged 17-23 years who were registered as voters by the KPU of Pariaman City. Determination of sample using Simple Random Sampling technique resulted in 100 samples. Data collection uses a liker scale. The data obtained were analyzed using simple regression. The results showed that the political literacy variable simultaneously had a significant effect on the political participation of first-time voters in Kota Pariaman in 2018.
\end{abstract}

Keywords : Political Literacy, Political Socialization, Political Understanding, Political Participation, Novice Voters

Corresponding author. Email.huzaifakatarudinumar@gmail.com,noraekaputri@fis.unp.ac.id

How to cite this article. Katarudin, H \& Putri, N. Eka. (2020). Pengaruh Literasi Politik terhadap Partisipasi Politik Pemilih Pemula pada Pemilukada Kota Pariaman Tahun 2018. Jurnal Mahasiwa Ilmu Administrasi Publik (JMIAP) Jurusan Ilmu Administrasi Negara Fakultas Ilmu Sosial Universitas Negeri Padang, Volume 2 (2), Hal. 70-79.

http://jmiap.ppj.unp.ac.id

ISSN : 2684-818X (Online), ISSN : 2338-7378 (Print)

Copyright $(2020$. Published by Pusat Kajian-Pemberdayaan dan Pelayanan Masyarakat (PK-P2M) FIS UNP Padang 


\section{PENDAHULUAN}

Salah satu proses terpenting dikehidupan bernegara di Indonesia pada era reformasi yakni penyelenggaraan pemilihan kepala daerah. Sistem demokrasi yang digunakan pada penyelenggaraan pemilu termasuk pemilu kada merupakan bentuk demokrasi yang tidak langsung (indirect democracy) yaitu Memperjuangkan kepentingankepentingan rakyat dengan pemberian legistmasi oleh masyarakat kepada kepala daerah untuk menjadi wakil rakyat. Sehingga melalui Pemilu yang di lakukan dan dipilih oleh masyarakat akan menghasilkan Kepala daerah yang menjadi wakil rakyat dalam memperjuangkan hakhak masyarakat. (sutrisno, 2017).

Dalam Rangka kegiatan Pemilu Kepala Daerah (Pemilu Kada) ini di harapkan masyarakat bisa memberikan peranannya sebagai komponen terpenting dalam elemen sistem politik di Indonesia. Pemilu Kada merupakan sarana memilih pemimpin daerah yang bisa membawa daerahnya relatif baik lagi kedepan dan mampu mencapai tujuan utama negara yaitu kesejahteraan sosial bagi seluruh rakyatnya. Untuk mewujudkan itu negara harus mampu mengayomi masyarakatnya untuk terjun langsung ke dalam proses pelaksanaan Pemilu Kada karena aspek terpenting dalam tatanan negara itu sendiri yaitu Partisipasi politik masyarakat, hal ini disebabkan partisipasi politik memiliki pengaruh relatif besar dalam keberlangsungan jalannya sebuah roda pemerintahan, karena masyarakat mempunyai legitimasi dalam memilih pemimpin untuk memimpin pemerintahan. Ini bisa dikatakan bahwa partisipasi politik dalam pilkada merupakan bentuk kontrol masyarakat terhadap roda kepemimpinan untuk pemerintahan yang berikutnya agar tidak ada yang dirugikan atas keputusan dari pemerintah. Kemudian P. Huntington dan Joan $M$ Nelson mendefinisikan partisipasi politik (Budiarjo, 2012) menjelaskan arti partisipasi politik secara luas yakni mempengaruhi pembuatan keputusan yang dibuat oleh pemerintah dengan cara tindakan tindakan pribadi yang berasal dari seseorang atau dari kegiatan keluarga. Bentuk partisipasi ini bisa jadi bersifat perseorangan atau kelompok yang dilakukan dengan tersusun atau secara tidak langsung tanpa ada kekerasan.

Semakin tinggi tingkat keikut sertaan politik rakyat memperlihatkan bahwa rakyat mengerti dan ikut serta pada kegiatan kenegaraan. Sebaliknya rendah nya partispasi politik secara umum mencerminkan bahwa rakyat tidak memberikan pemahaman dan hasrat pada permasalahan pada aktivitas kenegaraan. Bagi rakyat yang tidak memilih itu merupakan gambaran sikap golongan putih (Golput) dalam pemilu. Tingkat partisipasi politik yang rendah dan tinggi menjadi indikator penting terhadap jalannya proses demokrasi sehingga sangat menarik untuk di teliti.

Jadi dapat disimpulkan untuk mendapatkan hasil yang baik dalam kontestasi pemilihan umum yang terstruktur, partisipasi politik merupakan komponen utama agar bisa meningkatkan pemilihan umum yang memiliki partisipasi politik yang berkualitas dan berkuantitas. Tujuan dari partisipasi politik ini agar para pemilih bisa memahami dinamikadinamika politik yang sedang terjadi dan sedang berkembang. Pemahaman tentang politik bagi partipasi politik ini sangat peting. Salah satu bentuk upaya berdemokrasi oleh rakyat untuk menghasilkan pemimpin yang berkualitas danbertanggung jawab untuk melaksanakan tugasnya sebagai pelayan masyrakat yaitu dengan melakukan pemilihan umum yang diharapakan mampu mewujudkan kesejahteraan bagi masyarakat itu sendiri.

Salah satu upaya yang bisa dilakukan untuk meningkatkan partisipasi politik yaitu dengan literasi politik. Menurut Bernard Crick (Putri, 2015) mendefinisikan literasi politik adalah mengimplementasikan senyawa pengetahuan, keterampilan dan sikap mengenai politik dari hal hal kecil seperti isu-isu politik serta mempengaruhi diri sendiri dan oranglain dalam 
pengambilan keputusannya. Dengan adanya literasi politik ini para pemilih pemula bisa mendapatkan pendidikan politik yang membantu para pemilih pemula untuk bisa berpartispasi dalam kegiatan politik yang berhubungan dengan beberapa aspek seperti konsep Negara, kekuasaan, pengambilan keputusan dan kebijakan umum.

Di antara pemilih terdapat kategori pemilih yang relative menarik untuk di amati yakni pemilih pemula. Pemilih pemula merupakan orang yang pertama kali memberikan suaranya dalam pemilu. Pemilihan umum merupakan bentuk kegiatan demokrasi dari perwujudan kedaulatan rakyat yang dapat menghasilkan pemimpin yang berkualitas berdasarkan keinginan masyarakat.. (Wardhani, 2018). Warga Negara indonesia yang perdana menggunakan hak pilih nya dalam aktivitas pemilu dan mereka yang genap berusia 17 tahun atau belum berusia 17 tahun namun sudah menikah dikategorikan Pemilih pemula menurut Modul I Komisi Pemilihan Umum tahun 2013. Jadi dapat disimpulkan Pemilih pemula merupakan pemilih yang melakukan pemilu pertama kali dalam menentukan pilihannya dalam pemilu. Pemilih pemula sering kali mempunyai orientasi yang dinamis terhadap politik dan selalu berubah ubah ini disebabkan karena adanya indikator indikator yang mempengaruhin seperti lingkungan tempat tinggal, pendidikan, sosial budaya dan lain - lainnya. Kaum pemilih pemula yang terdiri dari kalangan pelajar tingkat SMA/Sederajat dan mahasiswa di sekisaran umur 17 hingga 21 tahun biasanya menjadi sasaran utama dalam pesta demokrasi. Jumlah pelajar dan mahasiswa yang banyak dijadikan sasaran tepat bagi para calon pemimpin dan partai partai politik untuk mendapatkan suaranya dalam pemilihan. Jika pelajar dan mahasiswa ini tidak memiliki pengetahuan dan wawasan yang mendalam tentang Politik tentu akan sangat mudah di pengaruhi.

Pada pemilu kada Kota Pariaman Tahun 2018 persentase pemilih pemula yang memberikan pilihannya hanya sebesar $20 \%$ dari total peserta pemilih pemula yang terdaftar di KPU Kota Pariaman tahun 2018. Sehingga dapat disimpulkan bahwa Kota Pariaman memiliki partisipasi yang relatif rendah di karenakan kurangnya pengetahuan masyarakat khususnya pemilih pemula terhadap pilkada serta tidak mengetahui betapa pentingnya pemimpin yang akan memimpin. Pemahaman politik bagi remaja di Kota Pariaman terbilang relative rendah. Menurut hasil wawancara penulis dengan Ibu Widya Hasan, S.Sos selaku staff pengelolaan rumah pintar pemilu KPU Kota Pariaman "Masyarakat di sini masih belum banyak menggunakan fasilitas yang kami sediakan terutama para remaja yang masih sekolah, mereka sangat minim sekali pengetahuan tentang politik dan terbukti rumah pintar pemilu KPU Kota Pariaman sepi pengunjung dari kalangan pelajar".

Maka penulis merasa tertarik untuk meneliti Pengaruh Literasi Politik terhadap Partisipasi Politik Pemilih Pemula pada Pemilu Kada Kota Pariaman Tahun 2018 yangn berdasarkan dari latar belakang masalah diatas.

\section{TINJAUAN PUSTAKA \\ Literasi Politik}

Bernard Crick (Putri, 2017) Literasi Politik adalah literasi politik adalah mengimplementasikan senyawa pengetahuan, keterampilan dan sikap mengenai politik dari hal hal kecil seperti isu-isu politik serta mempengaruhi diri sendiri dan oranglain dalam pengambilan keputusannya. Dengan adanya literasi politik ini para pemilih pemula bisa mendapatkan pendidikan politik yang membantu para pemilih pemula untuk bisa berpartispasi dalam kegiatan politik yang berhubungan dengan beberapa aspek seperti konsep Negara, kekuasaan, pengambilan keputusan dan kebijakan umum.

Melek politik atau Literasi Politik menurut Jenni S Bev Sebuah keterampilan dan pengetahuan bagi warga untuk berpartisipasi dalam pemerintah dan berkaitan dengan pelaksanaan tata Negara. 
Pada pelaksanaan pemilu melek politik dibedakan menjadi 2 jenis yakni Prosedural dan substansial. Melek substansial yakni mengerti pentingnya urgensi partisipasi politik sedangkan procedural yaitu memahami proses penyelenggaran dan prosedur prosedurnya.( Rosalia, 2016). Dari berbagai pengertian mengenai Literasi Politik dapat di simpulkan bahwa Literasi politik adalah sebuah upaya pemberian pemahaman tentang Politik kepada masyarakat agar mampu mengikuti kegiatan politik. Literasi Politik juga merupakan upaya mengimpretasikan pengetahuan atau wawasan mengenai politik dan isu - isu politik di kehidupan sehari hari agar masyarakat memiliki pengetahuan mengenai politik, partisipasi politik dan hal - hal yang mengenai politik sehingga masyarakat bisa memilih keadaan politik sesuai dengan pemahamannya.

\section{Partisipasi Politik}

Partipasi Politik menurut Sitepu (Wardhani Nur, 2018) adalah Aktifitas yang dilakukan secara individu maupun kelompok secara tidak langsung mengenai kebijakan yang dilakukan oleh pemerintah. Disisi lain dapat dipahami bahwa sebuah aktifitas aktifitas tersebut bisa dilakukan secara langsung atau pun tidak langsung, baik dengan memilih calon pemimpin atau mempengaruh kebijakan yang dibuat oleh pemerintah secara tidak langsung.

Definisi Partisipasi politik oleh Verba dan Nie (Putri, 2017) yakni Sebuah kegiatan untuk mempengaruhi pemilihan pemimpin secara langsung oleh individu atau warga negara yang bertujuan untuk kebersamaan dan kemakmuran masyarakat. Dan selanjutnya partisipasi Politik menurut Gaventa dan Valderama (Sahid, 2015) menyatakan bahwa partisipasi politik adalah Tindakan-tindakan politik seperti kampanye yang melibatkan oleh individu atau kelompok organisasi biasanya para partai politik dan negara dengan tujuan untuk meningkat partisipasi dalam kegiatan politik. Kemudian pendapat selanjutnya adalah Samuel P. Huntington dan Joam M.
Nelson (Budiarjo, 2012)menyatakan bahwa partisipasi politik adalah kegiatan yang dilakukan warga Negara sebagai individu untuk mempengaruhi proses pembuatan kebijakan oleh pemerintah yang bisa bersifat perseorangan ataupun kelompok.

\section{Pemilih Pemula}

Menurut PKPU Nomor 11 Tahun 2018 tentang Penyusunan Daftar Pemilih dalam negeri dalam penyelenggaraan pemilihan umum pasal 1 ayat 28 menjelaskan bahwa Warga Negara yang sudah genap berumur 17 tahun atau lebih atau sudah kawin atau pernah kawin di sebut dengan pemilih. Kategori Pemilih pemula adalah Warga Negara Indonesia pada saat pemilihan yang genap berusia 17 tahun dan mempunyai hak pilih untuk memilih berdasarkan ketentuan undang-undang pemilu.

\section{METODE PENELITIAN}

Metode yang digunakan pada penelitian ini adalah metode survey dengan pendekatan kuatitatif. Menurut Sugiyono (Sugiyono, 2017) yang dimaksud pendekatan kuantitatif adalah metode yang menggunakan pengambilan sampel nya melalui analisis data yang bersifat statistik / berupa angka angka dan di ambil secara randome serta berlandaskan pada filsafat positivism. Tujuan penelitian ini bermaksud untuk menguji hipotesis terhadap pengaruh Literasi politik tentang Pilkada terhadap partisipasinya dalam menggunakan hak pilih pada pemilu kada Kota Pariaman tahun 2018. Oleh karena pengumpulan data, proses, hingga analisis menggunakan data numerik maka penulis memilih menggunakan model analisis statistik untuk penelitian ini. Populasi pada penelitian ini adalah pemilih pemula seluruh pemilih pemula yang terdaftar sebagai pemilih di Pemilu kada Kota Pariaman pada tahun 2018. Berdasarkan sumber informasi yang diperoleh dari Kantor Komisi Pemilihan Umum Kota Pdigariaman diketahui bahwa terdapat 717 pemilih pemula di pemilu kada Kota Pariaman tahun 2018. Jenis teknis analisis datanya adalah analisis deskriptif, 
yaitu menggambarkan karakteristik dari populasi atau fenomena yang sedang diteliti. Analisis bertujuan untuk memprediksi atau mengestimasi keadaaan tertentu. Untuk menggambarkan karakteristik dari sampel/populasi yang sedang diteliti, maka hanya dilihat frekuensinya saja.

Teknik yang digunakan untuk memilih populasi sampel adalah Multistage Random Sampling mengambil sampel dengan cara bertahap dan pada setiap tahap dilakukan dengan metode simple random sampling (sampling secara acak sederhana) agar bisa menentukan wilayah kelurahan yang terpilih. Pengambilan sampel dilakukan secara acak dengan metode simple random sampling tanpa memperhatikan strata yang ada pada populasi. Jumlah sampel ini ditentukan menggunakan rumus slovin dengan tingkat kesalahan sebesar 10\%. Ada dua variabel dan beberapa indikator yang digunakan pada penelitian ini, adapun variabel dan indikator tersebut adalah:

Tabel 1. Variabel dan Indikator

\begin{tabular}{ll}
\hline \multicolumn{1}{c}{ Variabel } & \multicolumn{1}{c}{ Indikator } \\
\hline Literasi Politik & - Kebutuhan terhadap informasi politik \\
& - Strategi pencarian \\
& - Gerakan komunikasi informasi \\
& - Evaluasi produk dari proses akhir politik \\
\hline Partisipasi Politik & - Mengikuti diskusi Politik \\
& - Mengikuti Kampanye \\
& - Menggunakan Hak Pilih \\
\hline
\end{tabular}

Sumber: Data diolah oleh peneliti, 2020

HASIL DAN PEMBAHASAN

Adapun hasil dari penelitian ini digunakan untuk menjawab rumusan masalah pada artikel ini. Untuk itu dapat dilihat hasil analisis data oleh peneliti sebagai berikut :

Tabel 2. Hasil Uji Koefisien Determinasi Pengaruh Literasi Politik terhadap Partisipasi Politik

Model Summary

\begin{tabular}{ccccc}
\hline Model & $\mathrm{R}$ & $\begin{array}{c}\mathrm{R} \\
\text { Square }\end{array}$ & Adjusted R Square & Std. Error of the Estimate \\
\hline 1 & $.558^{\mathrm{a}}$ & .312 & .305 & 5.116 \\
\hline
\end{tabular}

Sumber : Data diolah oleh peneliti, 2020

Berdasarkan tabel 2 di atas, dari hasil pengujian menghasilkan nilai $\mathrm{R}$ sebesar $0.558^{\mathrm{a}}$ dan nilai $\mathrm{R}$ Square sebesar 0,312. Sementara nilai Adjusted R Square yang di hasilkan sebesar 0,305. Hasil berarti kontribusi variable Pengaruh Literasi Politik terhadap Partisipasi Politik adalah sebesar 31\%, sedangkan sisanya 69\% dipengaruhi oleh variabel lain yang tidak diteliti dalam penelitian ini. Selanjutnya nilai Adjusted R Square 0,305 atau sebesar $31 \%$ yang berarti kekuatan pengaruh literasi Politik mempengaruhi Partisipasi Politik pemilih pemula. Hal tersebut berarti Pengaruh Literasi Politik mempengaruhi Partisipasi Politik Pemilih Pemula Pada pemilu Kada Kota Pariaman Tahun 2018 sebesar 31\%. 
Huzaifa Katarudin, Nora Eka Putri I Pengaruh Literasi Politik terhadap Partisipasi Politik Pemilih Pemula pada Pemilukada Kota Pariaman Tahun 2018

Tabel 3. Hasil Uji t Pengaruh Variabel Literasi Politik terhadap Partisipasi Politik

\begin{tabular}{|c|c|c|c|c|c|c|}
\hline \multicolumn{7}{|c|}{ Coefficients $^{\mathrm{a}}$} \\
\hline & \multirow[t]{2}{*}{ Model } & \multicolumn{2}{|c|}{$\begin{array}{l}\text { Unstandardized } \\
\text { Coefficients }\end{array}$} & \multirow{2}{*}{$\begin{array}{c}\text { Standardized Coefficients } \\
\text { Beta }\end{array}$} & \multirow[t]{2}{*}{$\mathrm{T}$} & \multirow[t]{2}{*}{ Sig. } \\
\hline & & B & Std. Error & & & \\
\hline \multirow[b]{2}{*}{1} & (Constant) & 4.606 & 4.388 & & 1.050 & .296 \\
\hline & $\begin{array}{c}\text { Literasi } \\
\text { Politik(X) }\end{array}$ & .803 & .121 & .558 & 6.659 & .000 \\
\hline
\end{tabular}

Sumber : Diolah oleh peneliti, 2020

Hasil perhitungan pada tabel 3 di atas, didapatkan ersamaan regresi antara Literasi Politik (X) terhadap Partisipasi Politik (Y) adalah $\mathrm{Y}=4,606+0,803 \mathrm{X}$ dan dari hasil perhitungan tersebut didapatkan nilai $\mathrm{t}$ (hitung) 6,659 dan Sig. 0,000<0,05 hal ini menunjukkan hipotesis yang diajukan diterima dan menandakan bahwa Literasi Politik berpengaruh terhadap Partisipasi Politik Pemilih Pemula. Berdasarkan pada temuan yang telah dipaparkan oleh peneliti tentang Pengaruh Literasi Politik terhadap Partisipasi Politik Pemilih Pemula pada Pemilu kada Kota Pariaman tahun 2018. Setelah dilakukan penelitian dan telah dilanjutkan menganalisis data, dari analisis data yang telah dilakukan hal ini membuktikan secara parsial, variabel literasi politik memiliki pengaruh terhadap partisipasi politik pemilih pemula dengan nilai signifikansi 0.00 , berarti $\mathrm{H} 0$ di tolak dan Ha di terima.

Selanjutnya, variabel literasi politik berpengaruh secara signifikan terhadap kepuasan pengunjung karena nilai $\mathrm{R} 0.558$ atau sebesar $31 \%$ pada taraf signifikansi 0,000. Hal ini menunjukkan kekuatan variabel Literasi Politik dalam mempengaruhi Partisipasi Politik sebesar $31 \%$. Sehingga dapat dikatakan semakin besar kekuatan Pengaruh Literasi Politik maka semakin besar pula Partisipasi Politik Pemilih Pemula pada pemilu Kada Kota Pariaman Tahun 2018. Adapun $31 \%$ ini terdiri dari beberapa indikator literasi politik seperti Kebutuhan terhadap Informasi, Strategi Pencarian, Komunikasi informasi, dan evaluasi produk dari proses akhir politik.

\section{Kebutuhan terhadap Informasi}

KPU Kota Pariaman telah memanfaatkan Teknologi komunikasi dan informasi secara baik sehingga Pemilih pemula yang merupakan generas y dan $\mathrm{z}$ yang akrab dengan perkembangan revolusi 4.0 mendapatkan informasi melalui kecanggihan teknologi informasi yakni media online maupun media sosial. Ini dibuktinya bahwa KPU Kota Pariaman memiliki website resmi yang berisikan informasi mengenai informasi polititik maupun pemilu kada yang bebas di akses oleh masyarakat atau pemilih pemula di Kota Pariaman. Kemudian KPU Kota Pariaman juga memiliki facebook dan instagram .

Berdasarkan hasil observasi yang dilakukan di lapangan ini sangat membantu pemilih pemula untuk mendapatkan informasi politik hal ini sesuai dengan riset awal Campbell \& Kwak (2011) yang berisikan bahwa media sosial juga memiliki pengaruh terhadap partisipasi politik karena adanya asosiasi secara online dapat mendiskusikan politik dan masalah publik dimanapun dan kapanpun menggunakan akses internet.

\section{Strategi Pencarian/Pemahaman Tentang Calon}

Berdasar hasil riset peneliti di antara $31 \%$ yang mempengaruhi partisipasi politik juga di pengaruhi oleh pengetahuan tentang 
calon atau kandidat. Masyarakat atau khusus nya pemilih pemula mengetahui pengetahuan tentang calon atau kandidat melalui media sosialisasi atau alat kampanye yang dikeluarkan oleh KPU Kota Pariaman seperti Spanduk, Pamflet dan media cetak. Namun berdasarkan pertanyaan terbuka peneliti dan hasil observasi dilapangan bahwa pemilih pemula cenderung memilih mencari informasi kandidat melalui media sosial atau media online lainnya, ini membuktikan bahwa pemberian pemahaman atau pengetahuan tentang calon/kandidat melalui pamphlet, baliho dan media cetak tidak memiliki pengaruh yang signifikan. Pemilih pemula cenderung menggunakan sosial media. Salah satu contoh yaitu Genius Umar menang dalam pemilu kada Kota Pariaman karena memiliki akun instagram dengan 7.061 followers serta akun facebook dengan jumlah pengikut 5600 yang berisikan informasi mengenai dirinya maupun kampanye melalui media sosial yang dimilikinya.

Dapat disimpulkan bahwa saat ini pemilih (Voters) tidak hanya ingin mengetahui tentang kampanye kandidat saja melainkan juga tentang kehidupan serta latar belakang keluarga kandidat melalui sosial media yang dimiliki kandidat. Sehingga melalui observasi berdasarkan sosial media tersebut para pemilih semakin yakin untuk memilih karena melalui sosial media mereka tidak hanya mendapatkan informasi mengenai kampanye kandidat tetapi juga mendapatkan informasi mengenai family background kandidat atau biasa disebut melihat bibit bobot bebet kandidat.

\section{Mengkomunikasikan Informasi}

Berdasarkan hasil riset dilapangan KPU Kota Pariaman juga telah memberikan informasi secara terbuka kepada seluruh lapisan masyarakat. Ini terbukti dengan KPU Kota Pariaman bekerjasama dengan berbagai media massa di Kota Pariaman, sehingga informasi bisa didapatkan dengan mudah bisa melalui media cetak maupun media online seperti portal-portal berita yang di posting diinternet untuk mempermudah akses informasi.

\section{Evaluasi Proses Politik}

Agar terciptanya pemilihan kepala daerah yang aman dan berjalan lancar KPU Kota Pariaman juga bekerjasama dengan Bawaslu Kota Pariaman untuk menyukseskan pemilihan ini melalui berbagai cara salah satu Bawaslu memiliki website resmi yang bisa diakses secara terbuka oleh siapa saja dan bisa melakukan pelaporan online melalui Tools yang tersedia dilaman website tersebut sehingga masyarakat dan khususnya pemilih pemula juga memiliki kesempatan untuk memberikan saran untuk evaluasi atau Memberi saran apakah sesorang kandidat pantas pantas atau tidaknya. Penggunaan kotak saran atau pelaporan secara online ini memudahkan masyarakat khususnya pemilih pemula jika ingin melaporkan sesuatu tanpa harus datang ke kantor secara langsung yang akan menyita waktu.

Namun berdasarkan hasil observasi dilapangan literasi politik melalui penggunaan teknologi informasi ini hanya meningkatkan partisipasi untuk memilih saja tidak untuk melihat evaluasi setelah selesai pemilu kada. Ini terbukti bahwa pemilih pemula banyak tidak tau apakah program kerja yang dikampanyekan oleh kandidat yang terpilih itu terlaksana atau tidak terlaksana karena mereka hanya memilih dan tidak mengawal hasil dari proses pemilu kada tersebut sehingga banyak yang tidak tau apa saja yang sudah dijalankan oleh kandidat terpilih.

Dari temuan khusus yang ditemukan peneliti dapat disimpulkan bahwa Literasi Politik memiliki pengaruh terhadap partisipasi politik pemilih pemula terkhusus literasi politik yang melalui penggunaan teknologi informasi komunikasi baik secara elektronik, media cetak maupun online. Sementara literasi politik yang dilakukan secara konvensional tidak memiliki pengaruh yang signifikan terhadap pemilih pemula, inilah yang membedakan pemilih 
pemula dengan bukan pemilih pemula. Walaupun terdapat pengaruh literasi politik melalui sekolah dan keluarga namun tidak berpengaruh signifikan karena mereka adalah generasi yang akrab dengan penggunaan media (media literacy) sehingga penggunaan gadget/tablet lebih sering digunakan dibandingkan harus menerima informasi secara serius atau terpaku dari ibu/bapak guru dalam memberikan informasi politik yang membuatnya bosan dan stress.

Pemilih Pemula adalah generasi y dan z yang akrab mengikuti perkembangan revolusi industri 4.0 mencoba melakukan segala sesuatu dengan memanfaatkan penggunaan teknologi informasi dan komunikasi secara efektif dan efisien. Hal ini sesuai dengan penelitian yang telah dilakukan Ike Atikah Ratnamulyani dengan judul Peran Media Sosial Dalam Peningkatan Partisipasi Pemilih Pemula Dikalangan Pelajar Di Kabupaten Bogor. Penelitian ini menyimpulkan bahwa media sosial memiliki pengaruh yang cukup besar terhadap partisipasi pemilih pemula namun para politisi di Kota Bogor belum mampu mengoptimalkan pemanfaatannya.

Hasil penelitian ini memperkuat teori teori yang telah di jelaskan pada bab kajian teori yang mengatakan bahwa literasi politik memiliki pengaruh terhadap partisipasi pemilih pemula yang belum memahami bagaimana peran dan fungsi mereka dalam kegiatan politik. Dari teori yang di dapatkan dari Bernard Crick (Putri, 2017) bahwa Literasi Politik memiliki pengaruh yang cukup signifikan terhadap partisipasi politik masyarakat terkhususnya pemilih pemula. Literasi politik yang telah di lakukan oleh Komisi Pemilihan Umum Kota Pariaman memberikan dampak positif terhadap partisipasi politik pemilih pemula pada pemilu kada Kota Pariaman.

Sesuai dengan penelitian yang telah di lakukan oleh Nora Eka Putri (2017) dengan judul Dampak Literasi Politik terhadap partisipasi pemilih dalam pemilu. Penelitian tersebut menyimpulkan bahwa literasi politik memiliki pengaruh signifikan terhadap partisipasi pemilih, hal ini disebabkan karena literasi politik memberikan pemahaman dan pengetahuan mengenai pentingnya politik serta mengenai hal-hal terkait dengan pemilu kada itu sendiri seperti informasi pasangan calon, tata cara memilih, dan peran dalam pemilu kada tersebut.

Selanjutnya penelitian yang dilakukan oleh Agus Sutisna (2017) mengenai Peningkatan Literasi Politik Pemilih Pemula melalui Pendekatan Pembelajaran Kontekstual. Menyatakan melalui peningkatan literasi politik melalui pendidikan politik dapat mempengaruhi partisipasi politik pemilih pemula. Pengetahuan mengenai politik merupakan salah satu elemen penting pendukung minat pemilih pemula yang baru mengikuti kegiatan pemilihan umum satu hingga dua kali, sehingga pengetahuan akan hal tersebut sangat di butuhkan oleh pemilih pemula pada kegiatan politiknya baik pemilu kada maupun pemilu. Namun peneliti masih menemukan ada nya pemilih pemula yang tidak mendapatkan pemahaman politik dari KPU maupun agen sosialisasi politik yang akhirnya dalam pengisian angket sedikit mengalami kesulitan.

\section{PENUTUP}

Berdasarkan hasil temuan dan pembahasan yang telah dijelaskan sebelumnya, maka dapat penulis simpulkan bahwa: Literasi memiliki pengaruh terhadap partisipasi politik pemilih pemula terkhusus literasi politik yang melalui penggunaan teknologi informasi komunikasi baik secara elektronik, media cetak maupun online. Sementara literasi politik yang dilakukan secara konvensional tidak memiliki pengaruh yang signifikan terhadap pemilih pemula. Bahwa hari ini pemilih pemula akan tertarik dengan politik sambil bersantai, walaupun terdapat pengaruh literasi politik melalui sekolah dan keluarga namun tidak berpengaruh signifikan karena mereka adalah generasi yang akrab dengan penggunaan media 
(media literacy) sehingga penggunaan gadget/tablet lebih sering digunakan dibandingkan harus menerima informasi secara serius atau terpaku dari ibu/bapak guru dalam memberikan informasi politik yang membuatnya bosan dan stress. hal terbukti dengan pertanyaan terbuka kepada responden.

\section{DAFTAR KEPUSTAKAAN}

Adnan, M. F. (2012). Perilaku Memilih pada Pemilihan Kepala Daerah Secara Langsung. Padang: UNP Press.

Alrafni, S. (1999). Pemahaman Politik dan Identifikasi Kepartaian Perempuan dalam Pemilu 1999 di Kota Padang. (1996), 23-35.

Budiarjo. (2012). Dasar-dasar Ilmu Politik. Jakarta: CV. Prima Grafika.

Cucu, S. (2017). PARTISIPASI WARGA NEGARA DALAM PILKADA. Jurnal Pancasila Dan Kewarganegaraan, 2(2). Retrieved from http://journal.umpo.ac.id/index.php/JP $\mathrm{K} /$ index

Damsar. (2012). Pengatar Sosiologi Politik. Jakarta: Prenada Media Grup.

Hendriyadi, S. d. (2016). Metode Riset Kuantitatif. Jakarta: Prenada Media Grup.

Huntington, J. N. (1994). Partisipasi Politik di Negara Berkembang. Rineka Cipta.

Ir. Sofyan Siregar, M. (2015). Metode Penelitian Kuantitatif. Jakarta: Prenada Media Grup.

Kurniawan, R. C. (2013). Orientasi Politik Pemilih Pemula Pada Pilkada Pringsewu 2011 (Studi Pada Siswa/i SMUN di Kabupaten Pringsewu). Fiat Justitia Jurnal Ilmu Hukum, 7(1).

Levinsen, K., \& Yndigegn, C. (2015). Political discussions with family and friends: Exploring the impact of political distance. Sociological Review, 63(S2), 72-91. https://doi.org/10.1111/1467954X.12263

Miaz, P. (2012). Partisipasi Politik ( Pola Perilaku Pemilih Pemilu Masa Orde Baru dan Reformasi ). Padang: UNP Press.

PKPU No. 11 Tahun 2018. Tentang Penyusunan Daftar Pemilih Dalam Negeri Dalam Penyelenggaraan Pemilihan Umum.

Putri, N. E. (2015). Peningkatan Literasi Politik Melalui Kebijakan Berbasis Gender Di Kabupaten Solok. Kafa 'ah: Journal of Gender Studies, 5(1), 77. https://doi.org/10.15548/jk.v5i1.115

Putri, N. E. (2017). Dampak Literasi Politik terhadap Partisipasi Pemilih Pemula dalam Pemilu. 5, 1-115.

Sahid, K. (2015). Memahami Sosiologi Politik. Bogor: Ghalia Indonesia.

Sugiyono. (2017). Metode Penelitian Kuantitatif, Kualitatif, Dan Kombinasi (Mixed Methods) (Sutopo, ed.). Bandung: CV. ALFABETA.

Suryadi, B. (2007). Sosiologi Politik, Sejarah, Definidi, dan Perkembangan Konsep. Yogyakarta: IRCISOD.

Sutisna, A. (2017). Peningkatan literasi politik pemilih pemula melalui pendekatan pembelajaran kontekstual. Prosiding Seminar Nasional Pendidikan Fkip Untirta 2017.

Syarbaini. (2002). Sosiologi dan Politik. Bogor: Ghalia Indonesia.

Syarif, M. A. (2016). Pengaruh Sosialisasi Politik dan Status Sosial Ekonomi Terhadap Partisipasi Politik Pada Pemilihan Walikota 2015 di Kelurahan 
Huzaifa Katarudin, Nora Eka Putril Pengaruh Literasi Politik terhadap Partisipasi Politik Pemilih Pemula pada Pemilukada Kota Pariaman Tahun 2018

Air Putih Kota Samarinda. E-Journal Pemerintahan Integratif, 4(4), 547561. Retrieved from https://goo.gl/YZtaVE

Undang Undang NO. 8 Tahun 2015. Tentang perubahan atas undangundang nomor 1 tahun 2015 tentang penetapan peraturan pemerintah pengganti undang-undang nomor 1 tahun 2014 tentang pemilihan gubernur, bupati, dan walikota menjadi undang-undang.
Undang-undang No. 10 Tahun 2008. Tentang Pemilihan Umum Anggota Dewan Perwakilan Rakyat, Dewan Perwakilan Daerah, dan Dewan Perwakilan Rakyat Daerah.

Wardhani Nur, P. S. (2018). Partisipasi Politik Pemilih Pemula dalam Pemilihan Umum. Jupiis: Jurnal Pendidikan Ilmu-Ilmu Sosial, 10(1), 57.

https://doi.org/10.24114/jupiis.v10i1.8 407 